18. Amone-P'Olak K, Burger H, Huisman $\mathrm{M}$ et al. Parental psychopathology and socioeconomic position predict adolescent offspring's mental health independently and do not interact: The TRAILS study. Journal of Epidemiology and Community Health. 2011;65(1):57-63. Available from: http://dx.doi.org/10.1136/jech.2009.092569.

19. Rhee SH, Waldman ID. Genetic and environmental influences on antisocial behavior: A meta-analysis of twin and adoption studies. Psychological Bulletin. 2002;128(3):490-29. Available from: http://dx.doi.org/10.1037/0033-2909.128.3.490.

20. Piotrowska P, Stride C, Croft S, Rowe R. Socioeconomic status and antisocial behaviour among children and adolescents: A systematic review and metaanalysis. Clinical Psychology Review. 2015;35:47-55. Available from: http://www.sciencedirect.com/science/article/pii/S0272735814001652

21. Åslund C, Comasco E, Nordquist N, et al. Selfreported family socioeconomic status, the 5 - HTTLPR genotype, and delinquent behavior in a community - based adolescent population. Aggressive Behavior. 2013;39(1):52-63.

22. Dodge KA, Pettit GS, Bates JE. Socialization mediators of the relation between socioeconomic-status and child conduct problems. Child Development. 1994;65(2):649-65. Available from: http://dx.doi.org/10.1111/j.1467-8624.1994.tb00774.x.

23. Letourneau N, Duffet-Leger L, Levac L, et al. Socioeconomic status and child development: A metaanalysis. Journal of Emotional and Behavioral Disorders. 2013;21(3):211-224. Available from: http://dx.doi.org/10.1177/1063426611421007.

24. Stone S, Speltz M, Collett B, Werler M. Socioeconomic factors in relation to discrepancy in parent versus teacher ratings of child behavior. Psychopathology and Behavioral Assessment. 2013;35(3):314-20.

25. Veenstra R, Lindenberg S, Oldehinkel A, et. al. Temperament, environment, and antisocial behavior in a population sample of preadolescent boys and girls. International Journal of Behavioral Development. 2006;30(5):422-32. Available from: http://dx.doi.org/10.1177/0165025406071490.

26. Tuvblad C, Grann M, Lichtenstein P. Heritability for adolescent antisocial behavior differs with socioeconomic status: Gene-environment interaction. Journal of Child Psychology and Psychiatry. 2006;47(7):734-43. Available from: http://dx.doi.org/10.1111/j.14697610.2005.01552.x.

\title{
Г.I. Яськів
}

\section{ПЕРВИННА ТОКСИКОЛОГІЧНА ОЦІНКА НІТРОКСОЛІНУ НА ЛАБОРАТОРНИХ ТВАРИНАХ}

\author{
Львівський національний медичнийо університет ім. Данила Галищького \\ Центральна науково-дослідна лабораторія \\ вул. Пекарська, 69, Львів, 79010, Украӥна \\ Lviv national medical university of Danylo Halytskyy \\ Central research laboratory \\ Pekarska str, 69, Lviv, 79010, Ukraine \\ e-mail:annajaskiv@ukr.net
}

Ключові слова: Нітроксолін, параметри токсичності, шкірно-резорбтивний ефект, місиево-подразнююча дія, кумулятивна активність

Key words: Nitroxoline, parameters of toxicity, skin-resorptive effect, locally irritating effect, cumulative activity

Реферат. Первичная токсикологическая оценка нитроксолина на лабораторных животных. Яскив А.И. Нитроксолин - эффективный антибактериальный препарат, который промылиенно выпускается химико- 
фармацевтическими предприятиями Украиньл. Устанавливали параметры токсичности нитроксолина в условиях острых и субхронического токсикологических экспериментов на 3-х видах лабораторных жсивотных, путем введения препарата внутрь, нанесения на кожу и слизистие оболочки. Продолжстельность острого опьлта составляла 14 суток, субхронического - 24 суток. Установлено, что средне смертельная доза (DL 50$)$ для бельх крыс-самок составляет 980 (852:1127) мг/кг, бельхх крыс-самиов - 835 мг/кг, бельх мылией-самиов 660 мг/кг и позволяет отнести препарат за этим параметром к 3 классу опасности - вещества умеренно опасные. Средне эффективное время гибели жсивотных (ET $\left.T_{50}\right)$ для бельх крыс равно 28 часам. Видовая чувствительность лабораторных животных к нитроксолину слабо виражена. Смерть животных наступает начиная с первых суток после введения и регистрируется в течение трьох дней. При нанесении на неповрежденную кожу местно-раздражаюшиий и кожно-резорбтивный эффекть отсутствуют. При попадании на слизистые оболочки глаз препарат вызывает слабый раздражсаючий эффект. Нитроксолин обладает умеренной кумулятивной активностью.

\begin{abstract}
Absract. Primary toxicological evaluation of nitroxoline on laboratory animals. Yaskiv G.I. Nitroxoline is an effective antibacterial agent that is industrially produced by chemical and pharmaceutical enterprises in Ukraine. Parameters of its toxicity are determined under conditions of acute and subchronic toxicological experiments on 3 kinds of laboratory animals, by administering the drug orally and by application onto the skin and mucous membranes. The duration of acute experiment was 14 days, subchronical - 24 days. It was found that median lethal dose (DL $\left.L_{50}\right)$ for white female rats is 980 (852:1127) mg/kg, of white male rats - $835 \mathrm{mg} / \mathrm{kg}$, white male mice- $660 \mathrm{mg} / \mathrm{kg}$, by this parameter the drug can be attributed to 3 class of hazard - moderately hazardous substance. Average effective time of death (ET 50$)$ for albino rats is 28 hours. Species sensitivity of laboratory animals to nitroxoline is slightly expressed. The death of the animals starts on the first day after the injection and is recorded during three days of the experiment. In application on intact skin, locally-irritant and skin-resorptive effects are absent. After contact with the mucous membrane of the eye the drug causes weak irritant effect. Nitroxoline has a moderate cumulative activity.
\end{abstract}

Фармацевтичний ринок України представлений численними антибактеріальними препаратами, кількість найменувань яких щорічно зростає. Одним з ефективних препаратів, який вже тривало застосовують, є нітроксолін [5]. Випуск препарату здійснюють: ПАТ «Київський вітамінний завод» м. Київ, ПАТ НВЦ «Борщагівський хіміко-фармацевтичний завод» м. Київ, ПАТ «Технолог» м.Умань Черкаська обл. та ПАТ «Вітаміни» м. Умань Черкаська область.

У рамках розробки гігієнічного нормативу допустимого вмісту нітроксоліну в повітрі робочої зони виробничих приміщень проведена токсикологічна оцінка препарату на лабораторних тваринах.

Метою цього дослідження $є$ встановлення параметрів токсичності нітроксоліну в умовах гострих та субхронічного токсикологічного експериментів на лабораторних тваринах.

\section{МАТЕРІАЛИ ТА МЕТОДИ ДОСЛІДЖЕНЬ}

Нітроксолін - 5-нітро-8-хінолінол (нітроксолін). Синоніми: 5-нітро-8-оксихінолін, 5-НОК, Нібіол, Нітрокс, 5-Nitrox, 5-Nitroxine, BAS 58, Nibiol, Nitroquinolines, Noxin, Uritrol. CAS № 4008-48-4. Емпірична формула: $\mathrm{C}_{9} \mathrm{H}_{6} \mathrm{~N}_{2} \mathrm{O}_{3}$, молекулярна маса: 190,16. За зовнішнім виглядом це порошок від коричнево-жовтого до коричневого кольору, слабко розчинний у 95\% спирті, важко розчинний у хлороформі, в ацетоні. Легко розчинний у лугах та кислотах. Малорозчинний у воді, розчинність за t $25^{\circ} \mathrm{C}$ становить 3,73 г/л препарату. Температура плавлення: $182^{0} \mathrm{C}$.

Токсикологічну оцінку нітроксоліну проводили згідно з методичними вказівками [2, 3]. Було використано три види лабораторних тварин: статевозрілі безпородні білі щурі 3 масою тіла 200-220г, білі безпородні миші - 20-24 г та один кріль, які утримувались в умовах віварію Львівського національного медичного університету на стандартному харчовому раціоні, згідно 3 санітарно-гігієнічними нормами. Дослідження проведені 3 дотриманням правил гуманного поводження 3 тваринами згідно 3 правилами Свропейської конвенції по захисту тварин. Експериментальні групи в дослідах включали по 6-10 особин кожна і складались шляхом формування ранжувальних рядів за зростаючою масою тіла.

Вивчення токсичних властивостей препарату в гострому досліді проводили шляхом введення внутрішньошлунково водної суспензії нітроксоліну. Тварин спостерігали упродовж 14 діб.

Місцево-подразнювальну та шкірно-резорбтивну дію нітроксоліну вивчали "пробірочним методом" на білих щурах, шляхом занурювання 2/3 хвоста білих щурів у водний розчин препарату тривалістю 4 години упродовж 10 днів [3]. Місцевий вплив засобу досліджували на слизовій оболонці кроля, шляхом внесення 50 мг препарату в кон'юнктивальний мішок ока. Зміни спостерігали упродовж 14 діб. Оцінювали 
ступінь пошкодження слизової оболонки ока методом А. Majda i K. Chrusaielska (1965 р.) [6].

Кумулятивну активність нітроксоліну вивчали за методикою Lim et all. [4]. Нітроксолін вводили перорально білим щурам-самкам у вигляді ненасиченого водного розчину починаючи 3 0,1 $\mathrm{DL}_{50}$ і вище, шляхом збільшення дози в 1,5 рази кожні 4 доби упродовж 24 днів.

\section{РЕЗУЛЬТАТИ ТА ЇХ ОБГОВОРЕННЯ}

Встановлено, що при однократному пероральному введенні нітроксоліну білим щурам у дозах від 600 мг/кг до 1200 мг/кг та білим мишам у дозах від 300 мг/кг до 600 мг/кг розвивається гостре отруєння. Доза препарату 600 мг/кг у білих щурів-самок викликає короткочасне збудження (тварини безладно пересуваються по клітці) та симптоми подразнюючої дії (занепокоєння тварин, тертя мордочки, заплющення очей), спостерігається слабка реакція на зовнішні подразники.

При введенні препарату в дозах 800 мг/кг, 1000 мг/кг та 1200 мг/кг знижується рухова активність, з'являються в'ялість, загальна слабкість, адинамія, тварини залягають на живіт. Спостерігаються симптоми ураження центральної нервової системи: слабка реакція на зовнішні подразники, спастичне нечасте дихання, судоми, горбовидна спина, ригідність м'язів хвоста (симптом Штраубе). Загибель білих щурів і білих мишей реєструється упродовж 1-3 діб.

Залежність загибелі тварин від доз нітроксоліну, що вводились, представлена в таблиці.

\section{Динаміка загибелі тварин при одноразовому введенні нітроксоліну}

\begin{tabular}{|c|c|c|c|c|c|c|c|c|c|}
\hline \multirow{2}{*}{ Дози, мг/кг } & \multirow{2}{*}{$\begin{array}{l}\text { Кількість } \\
\text { тварин }\end{array}$} & \multicolumn{6}{|c|}{ Терміни спостереження, доби } & \multirow{2}{*}{$\begin{array}{c}\text { Кількість тварин, } \\
\text { що загинули }\end{array}$} & \multirow{2}{*}{$\begin{array}{c}\text { Частка тварин, що } \\
\text { загинули \% }\end{array}$} \\
\hline & & 1 & 2 & 3 & 4 & 5 & 14 & & \\
\hline 600 & 6 & $\mathbf{0}$ & $\mathbf{0}$ & $\mathbf{0}$ & $\mathbf{0}$ & $\mathbf{0}$ & $\mathbf{0}$ & $\mathbf{0}$ & $\mathbf{0}$ \\
\hline 800 & 6 & 1 & $\mathbf{0}$ & $\mathbf{0}$ & $\mathbf{0}$ & $\mathbf{0}$ & $\mathbf{0}$ & 1 & 16,7 \\
\hline 1000 & 6 & 1 & 1 & 1 & $\mathbf{0}$ & $\mathbf{0}$ & $\mathbf{0}$ & 3 & 50,0 \\
\hline 1200 & 6 & 4 & 1 & $\mathbf{0}$ & $\mathbf{0}$ & $\mathbf{0}$ & $\mathbf{0}$ & 5 & 83,3 \\
\hline
\end{tabular}

Частка загибелі тварин упродовж трьох діб становила для дози $800-1 / 6$, для дози $1000-3 / 6$, для дози 1200 - 5/6. Середньо ефективний час загибелі $\left(\mathrm{ET}_{50}\right)$ для білих щурів дорівнює 28 годин.

$\mathrm{DL}_{50}$ для білих щурів-самок становить 980 (852:1127) мг / кг, білих щурів самців - 835 мг/кг, білих мишей-самців - 660 мг/кг (3 клас небезпеки - помірно небезпечні речовини, згідно 3 ГОСТ 12.1.007-76).

Статева чутливість слабо виражена. Коефіцієнт видової чутливості (КВЧ) становить 1,17 та свідчить про слабо виражену міжвидову чутливість.

Ступінь (індекс) токсичності для щурів-самок розрахований на рівні 0,0010, для щурів-самців 0,0012, для мишей-самців 0,0015.

Занурення 2/3 хвоста білих мишей у ненасичений водний розчин нітроксоліну тривалістю 4 години упродовж 10-и днів не викликало загибелі тварин, змін на шкірі та видимих ознак гострої інтоксикації.

Внесення 50 мг нітроксоліну в кон'юнктивальний мішок ока кроля викликало слабку подразнюючу дію: виділення 1 бал, за класифікацією Maida A., Chrusaielska K. [3].
Для визначення кумулятивної активності препарат вводили білим щурам-самкам у вигляді ненасиченого водного розчину починаючи 30,1 $\mathrm{DL}_{50}(98,0$ мг/кг) і вище шляхом збільшення дози в 1,5 рази кожні 4 доби. Перші 4 доби тварини одноразово отримували по 0,1 $\mathrm{DL}_{50}, 5-8$ доба 0,15 $\mathrm{DL}_{50}, 9-12$ доба - 0,22 $\mathrm{DL}_{50}, 13-16$ доба 0,34 $\mathrm{DL}_{50}, 17-20$ доба - 0,5 $\mathrm{DL}_{50}, 21-24$ доба $0,75 \mathrm{DL}_{50}$. [6]. Всього було проведено 24 введення препарату. Сумарна $\mathrm{DL}_{50}$ нітроксоліну становила 4900 мг/кг. Загибель тварин відмічали починаючи 312 доби. Коефіцієнт кумуляції становить 5,0, що означає, що речовина володіє помірною кумулятивною активністю.

\section{ВИСНОВКИ}

1. Нітроксолін за критерієм гострої пероральної токсичності належить до 3 класу небезпеки речовини помірно небезпечні. Встановлено слабо виражену видову чутливість тварин до дії препарату.

2. При потраплянні на слизову оболонку очей нітроксолін володіє слабким подразнювальним ефектом. Шкірно-резорбтивна та місцево-подразнювальна дія при потраплянні препарату на шкіру відсутня. 
3. Нітроксолін проявляє помірну кумулятивну активність.

Перспективи подальших досліджень. У рамках розробки гігієнічного нормативу необхідно до- слідити вплив препарату в умовах хронічних дослідів, вивчити віддалені наслідки дії (гонадотоксичний, ембріотоксичний та мутагенний ефекти).

\section{СПИСОК ЛІТЕРАТУРИ}

1. Методические указания к постановке исследований для обоснования санитарных стандартов вредных веществ в воздухе рабочей зоны: метод. указания № 2163-80. - Москва, 1980. - 20 с.

2. Обгрунтування гранично допустимих концентрацій лікарських засобів у повітрі робочої зони і в атмосферному повітрі населених місць: метод. вказівки № 544, затверджені наказом МО3 України від 21.10.2005 р. - Київ, 2015. - 19 с.

3. Оценка воздействия вредных химических соединений на кожные покровы и обоснование пре- дельно допустимых уровней загрязнения кожи: МУ 2102-79. - Москва, 1980. - 23 с.

4. A method for the evaluation of cumulation and tolerance by the determination of acute and subchronic median effective doses / R.K. Lim, K.G. Rink, H.G. Glass, E.A. Soaje-Echague // Arch. Inter. Pharm.-1961.- Vol. 130.- P.336-352.

5. Bergogne-Berezin El. Present status of nitroxoline / E1. Bergogne-Berezin, G. Berthelot, C. Muller-Serieys. // Pathol Biol (Paris). - 1987. - Vol. 35. - P. 873-878.

6. Maida A., Chrusaielska K. // Medicine Pracy. 1965. - Vol. XXX1V. - P. 321-396.

\section{REFERENCES}

1. [Guidelines for the formulation of research to substantiate the health standards of harmful substances in the working area: Method. directions N 2163-80]. Moskva, 1980;20. Russian.

2. [Rationale for the maximum permissible concentration of drugs in the air of the working area in the ambient air of places: Method. instructions N 544, 2005]. Kyiv, MOZ Ukrainsky, Kyiv, 2015;19. Ukrainian.

3. [Assessment of the impact of hazardous chemicals on the skin and justification of maximum per- missible levels of skin contamination: ME 2102-79]. Moscow, 1980;23. Russian.

4. Lim RK, Rink KG, Glass HG, Soaje-Echague EA. A method for the evaluation of cumulation and tolerance by the determination of acute and subchronic median effective doses. Arch. Intern. Pharm. 1961;130:336-52.

5. Bergogne-Berezin E1, Berthelot G, Muller-Serieys C. Present status of nitroxoline. Pathol Biol (Paris). 1987;35:873.

6. Maida A, Chrusaielska K. Medicine Pracy. 1965;XXX1V:321-96. 